\title{
Light Dependency in Celery Somatic Embryogenesis and Plantlet Development in Suspension Culture
}

\author{
Nobuyuki Uozumi*, Katsuhito KoHKetsu*, \\ Akihiro OKамото** and Takeshi KoвayAshi* \\ *Department of Biotechnology, Faculty of Engineering, \\ Nagoya University, Chikusa-ku, Nagoya, 464-01 Japan \\ ${ }^{* *}$ Plant Laboratory, Kirin Brewery, Co., LTD. \\ 3377 Kitsuregawa-machi, Shioya-gun, Tochigi, 329-14 Japan
}

(Received September 2, 1992)

(Accepted November 16, 1992)

\begin{abstract}
We analyzed the light requirements for celery somatic embryogenesis and plantlet development. The regeneration period was divided into two stages. During the first stage, in which torpedo-shaped embryos were mainly produced from the embryogenic callus, light stimulated chlorophyll synthesis. Although under dark conditions cells were slow in embryo formation, prolonged culture in the dark led to the production of globular-, heart- and torpedo-shaped embryos. The torpedo embryos were ready to become healthy plantlets after the second-stage culture under light conditions. Light enhanced the embryo formation rate, but was not obligatory on embryo formation. In the second stage, a 16-h photoperiod and a higher light intensity gave the maximum frequency of plantlet development, and were essential for the production of the healthy plantlets in terms of size (more than $850 \mu \mathrm{m}$ ). The results strongly suggest that illumination can be reduced at the beginning of the first regeneration stage, but that increased illumination is required after the torpedo embryo development has progressed.
\end{abstract}

\section{Introduction}

Plant cells in nature possess the flexibility of differentiation and dedifferentiation, i.e., totipotency. Totipotency is essential for experiments involving regeneration. Reinert( ${ }^{1)}$ and Steward et al. ${ }^{2}$ were the first to report somatic embryogenesis. To date, the regeneration of a number of plants through somatic embryogenesis has been reported by modifying the type or concentration of nutrients and plant growth regulators. The proliferation and development of asexual embryos in vitro led us to speculate that a large number of clonal seeds would be obtainable even from sterile plant tissue or organs. These findings resulted in the concept of artificial or synthetic seeds proposed by Murashige ${ }^{3}$. Although a number of types of somatic embryo have been induced, there are only a few plant cells in which a proper culture process has been established to obtain a high frequency of embryogenesis or regeneration without a large amount of nonembryogenic callus production. The procedures for somatic embryogenesis of alfalfa, celery and rice have been studied extensively ${ }^{4-7)}$. The results of these works will enable the production of artificial seeds that can be planted directly in soil.

Artificial seeds are regarded as a delivery system for the high-yield and low-cost propagation of elite plants and an alternative to zygotic seeds. To realize commercially useful artificial seeds, it is important to develop efficient culture conditions in terms of yield, quality and cost. 
With regard to the physical conditions necessary for regeneration from embryogenic callus, light seems to be one of the important factors associated with regeneration, and one of the factors to be considered in bioreactor design and the efficient control of culture conditions for artificial seed production on a large scale. From the viewpoint of molecular biology, the red: far-red system which involves phytochrome plays an important role in germination from zygotic seeds ${ }^{8,9)}$, but there is little information about the light conditions needed to obtain efficient culture for somatic embryogenesis.

The aim of this study is to evaluate the light requirements for celery somatic embryogenesis and plantlet development. Light dependency in somatic embryogenesis from celery callus is evaluated using illumination with commercial light tubes. The results show that while light is not essential for morphological development from callus up to the development of torpedo-shaped embryos, it shortens morphological development. After torpedo embryo fromation, light contributes effectively to healthy plantlet formation.

\section{Materials and Methods}

\section{Plant materials and culture conditions}

Celery $F_{1}(1026-2)$ callus $^{10,11)}$ was used in all experiments. The somatic embryogenesis and plantlet development procedure employed was as has been reported ${ }^{10-12)}$, but with slight modifications. For callus growth, callus passed through a $1000 \mu \mathrm{m}$ sieve was subcultured in liquid SH medium ${ }^{13)}$ containing $2,4-\mathrm{D}$ and $3 \%$ (W/V) sucrose in a shake flask ( $80 \mathrm{rpm}$ ) at $25^{\circ} \mathrm{C}$ under dark conditions. Embryogenic callus clusters were selected by passing the subcultured cells through a 600 $\mu \mathrm{m}$ sieve in the first regeneration stage. After the embryogenic callus was washed several times, somatic embryogenesis was initiated by transferring $0.4 \mathrm{~m} l$ packed cell volume (pcv) of the embryogenic callus to $100 \mathrm{~m} l \mathrm{SH}$ medium containing $8 \%$ mannitol and $10 \mathrm{ng} / \mathrm{L}$ zeatin in $500-\mathrm{m} l$ Erlenmeyer flasks under fluorescent white light. After torpedo-shaped embryos appeared in the culture, the cells were harvested, and then passed through an $850 \mu \mathrm{m}$ mesh for the second regeneration stage. Following pcv measurement, an $0.4 \mathrm{ml} \mathrm{pcv}$ aliquot of cells less than $850 \mu \mathrm{m}$ was resuspended into $100 \mathrm{~m} l \mathrm{SH}$ medium with $3 \%$ sucrose in $500-\mathrm{m} l$ Erlenmeyer flasks under light conditions. When the plantlets grew, cells which did not pass through an $850 \mu \mathrm{m}$ sieve were classified as healthy plantlets. A sample $(1 \mathrm{ml})$ was taken from each flask with a sterilized pipette for measurement under a microscope of the number of developed embryo, and of the chlorophyll content.

\section{Chlorophyll content assay}

Chlorophyll was extracted by homogenizing the cells in acetone using a mortar and pestle followed by repeated washing with $80 \%$ acetone until the cells became colorless. Tissue debris was removed by filtration. The volume of the filtrate was adjusted to $10 \mathrm{~m} l$ with $80 \%$ acetone. The total amount of chlorophyll was determined by absorbance readings at $645 \mathrm{~nm}$ and $663 \mathrm{~nm}$, as described by Arnon ${ }^{14)}$.

\section{Results and Discussion}

\section{Light-dependent morphological development during the first regeneration stage}

In general, it is difficult to assess clearly light dependency in morphlogical development from callus, since the efficiency and synchrony of morphological development in many types of plant cells has not been completely established. We selected celery for this study on the grounds that celery callus exhibits relatively high efficiency in somatic embryogenesis. 


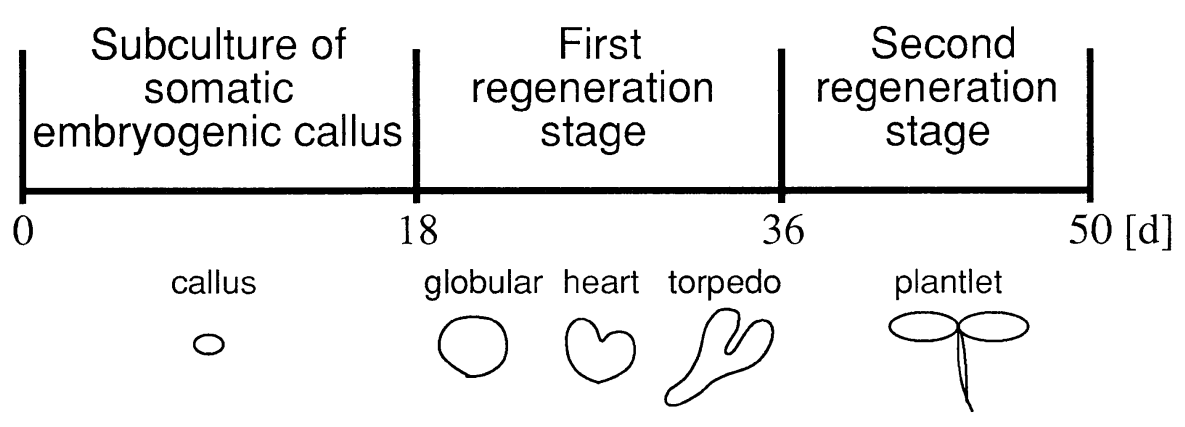

Fig. 1 Regeneration stages and the major morphological events during celery embryogenesis.

Onishi et $a l .{ }^{10,11)}$ determined the culture conditions for celery regeneration. By using their procedure, celery plantlets as artificial seeds were obtained efficiently. The regeneration period from celery callus to plantlet can be divided into two stages by medium replacement, as described in Materials and Methods. Preliminary experiments on regeneration were carried out using a photoperiod of $16 \mathrm{~h}$ a day, and a light intensity of $3800 \mathrm{~lx}$. The celery callus obtained from the callus subculture was transferred to fresh medium without auxin. After 18 days, the cells turned light green. Microscopic observation showed that the callus had altered to form globular-, heart- or torpedo-shaped embryos in this stage (see below). An aliquot from the 18-day subculture was transferred to fresh medium under the same light conditions. Cotyledons appeared from clusters of cells during this stage. The cells at 14 days turned dark green and became healthy plantlets. Having determined the culture schedule, which is summarized in Fig.1, all subsequent studies were performed according to this schedule.

During the first regeneration stage, the photoperiod affected the chlorophyll content of cell
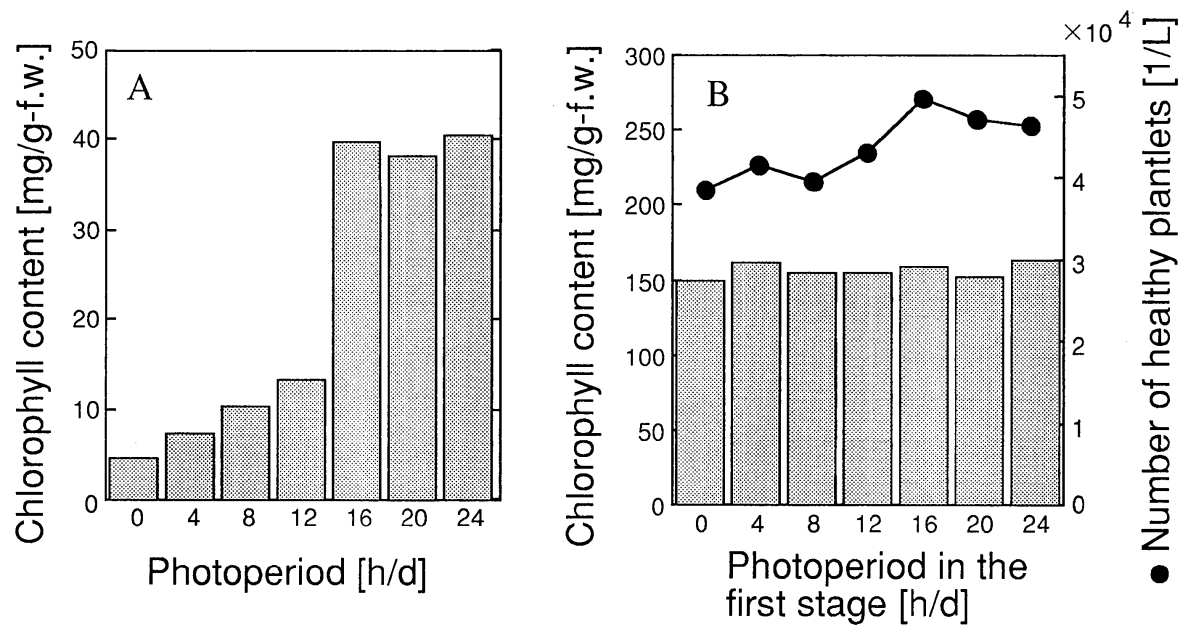

Fig. 2 Effect of photoperiods on morphological development in the first regeneration stage.

A : Chlorophyll content (匹) at the end of the first regeneration stage. Cells were cultured at constant light intensity ( $3800 \mathrm{~lx}$ ) under various photoperiods.

$\mathrm{B}$ : Cells were cultured as above in the first stage, followed by the second stage culture for 14 days with a $16-\mathrm{h}$ photoperiod and at $3800 \mathrm{~lx}$. The chlorophyll content (罒) was evaluated at the end of the second regeneration stage. The number of healthy plantlets (O) at the end of the second regeneration stage was estimated on the basis of inoculation of $4 \mathrm{~m} l \mathrm{pcv}$ of cells in the first regeneration stage. 

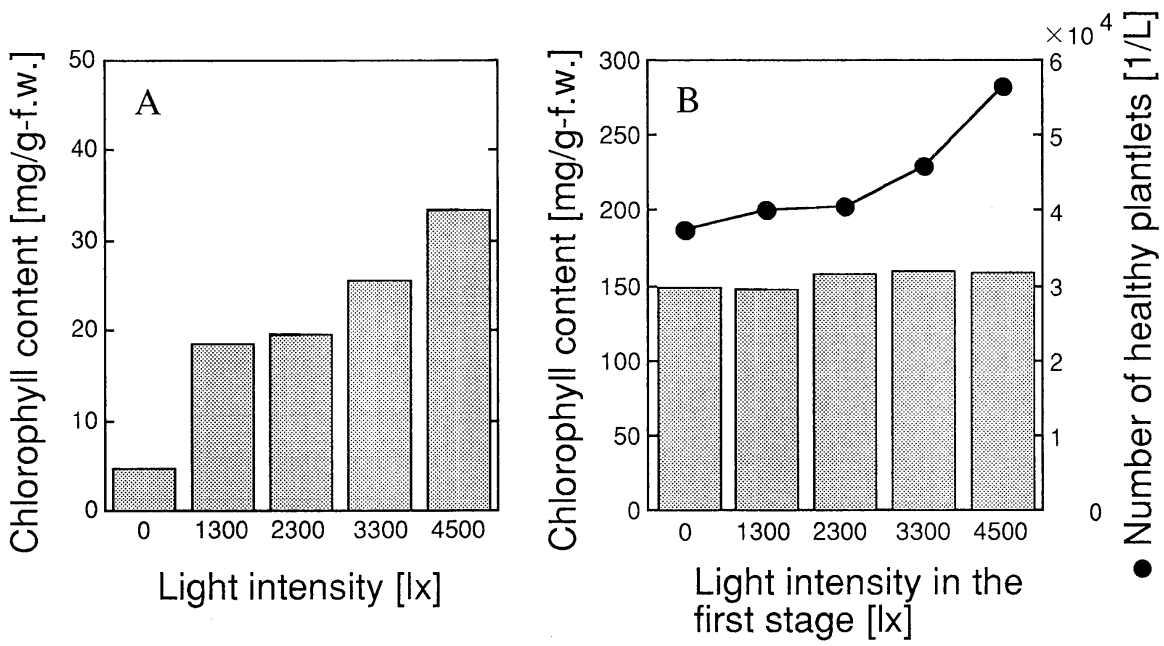

Fig. 3 Effect of light intensity on morphological development in the first regeneration stage.

A : Chlorophyll content $(\mathbb{Z})$ at the end the first regeneration stage. Cells were cultured with a 16$\mathrm{h}$ photoperiod under various light intensities.

$B$ : Cells were cultured as above in the first stage, followed by the second regeneration stage culture

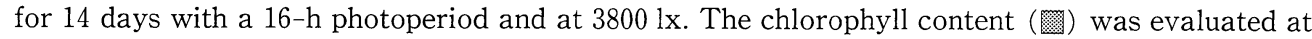
the end of the second regeneration stage. The number of healthy plantlets ( ) at the end of the second regeneration was estimated in the same manner as in Fig. 2.

clusters (Fig. 2). For use as an artificial seed, a plantlet requires adequate development in size, shape and color; thus we selected plantlets of more than $850 \mu \mathrm{m}$ in diameter and measured the chlorophyll content as an indicator of the greening level. A longer photoperiod enhanced the chlorophyll content in the cells, which reached a maximum level at a photoperiod of $16 \mathrm{~h}$ or more (Fig. 2-A). To count the number of embryos with regeneration ability, the cells were transferred to the second stage for 14 days to grow into healthy plantlets under fixed light conditions (16-h photoperiod, 3800 lx). Fig. 2-B shows that the chlorophyll content per cell in cells cultured with various photoperiods in the first stage reached almost the same level at the end of the second stage culture. However, a 16-h light-culture in the first stage produced the maximum number of healthy plantlets. The number of healthy plantlets under the various photoperiod conditions ranged from 38,000 to 50,000 in $1 \mathrm{~L}$-culture, which means that there was little effective difference in morphological developmet among the 0 - through $24-\mathrm{h}$ photoperiods in the first stage. Even callus cultured under completely dark conditions in the first regeneration stage synthesized chlorophyll at the end of the 14-day culture in the second stage. This result strongly suggests that plastids were organized in the cell during the first stage under dark conditions. Although celery callus had the capability of morphological development in the absence of light during the first stage, illumination did constitute a major physical and environmental limiting factor in this stage.

Fig. 3 represents the dependence on light intensity of healthy plantlet development during the second regeneration stage. Although the amount of chlorophyll at the end of the first stage increased as the light became more intense, the chlorophyll contents of all these calli after the second regeneration stage under fixed light conditions (16-h photoperiod, $3800 \mathrm{~lx}$ ) were similar. Lightculture at $4500 \mathrm{~lx}$ resulted in the highest number of healthy plantlets, while the numbers of healthy plantlest generated at light intensities from 0 through $2300 \mathrm{~lx}$ did not differ significantly. Illumination was not therefore essential, but was effective in achieving healthy plantlet development during the first regeneration stage. 


\section{Microscopic observation of embryo formed during the first regeneration stage}

At 18 days in the first-stage culture under light conditions, embryos were dark yellow and partially light green, while in culture under dark conditions they did not turn green but dark yellow. To assess the light dependency in the somatic embryogenesis, morphological development during the first regeneration stage was observed under a microscope. As shown in Table 1, the dark culture showed efficient globular-or heart-shaped embryo development, the number of which was slightly less than (14 days and 18 days) or comparable (28 days) to that of cells cultured in the 16-h photoperiod. On the other hand, there was a significant difference in the number of torpedo-shaped embryos between the dark and light cultures. Another important point is that total number of embryos in the dark and 16-h light cultures at 28 days increased 3.9 and 2.9 times, compared with those at 18 days respectively. Thus, although an 18-day culture was employed in the first stage in this study, it would have been better if a 28-day culture had been used for embryo production during the first regeneration stage.

Table 2 shows the effect of light intensity on morphological development after 18 days culture with a $16-\mathrm{h}$ photoperiod. The differences in the number of globular and heart embryos cultured under various light intensity conditions were small, but the number of torpedo embryos increased with increasing light intensity.

Torpedo embryos formed during the first stage possess sufficient ability for plantlet development during the second regeneration stage. Judging from the results shown in Fig. 2-B and Table 1, and in Fig. 3-B and Table 2, 6-10\% of the globular and heart embryo formed during the first stage could also develop into plantlets during the second regeneration stage.

Kitto and Jarick ${ }^{15)}$ proposed that carrot embryogenesis culture should be performed under light conditions. However, our results obtained with a celery system showed that light was not essential for the initial embryogenesis up to globular or heart embryo formation. The main trigger factor in initiating embryogenesis seems to be not illumination, but auxin elimination from the regeneration medium $^{16)}$.

Table 1. Effect of photoperiod on morphological development during the first regeneration stage*1.

\begin{tabular}{cccc}
\hline \multirow{2}{*}{ Culture time $(\mathrm{d})$} & Plant-cell shape & \multicolumn{2}{c}{ Number of embryos developed $(/ \mathrm{L})^{* 2}$} \\
\cline { 3 - 4 } & & $0 \mathrm{~h} / \mathrm{d}$ & $16 \mathrm{~h} / \mathrm{d}$ \\
\hline \multirow{2}{*}{14} & globular, heart & 50,000 & 65,000 \\
& torpedo & 0 & 0 \\
& total & 50,000 & 65,000 \\
\hline \multirow{2}{*}{18} & globular, heart & $305,000(10 \%)^{* 3}$ & $375,000(7.5 \%)$ \\
& torpedo & 8,000 & 22,000 \\
& total & 313,000 & 397,000 \\
\hline \multirow{2}{*}{28} & globular, heart & $1,090,000$ & 985,000 \\
& torpedo & 143,000 & 180,000 \\
& total & $1,233,000$ & $1,165,000$ \\
\hline
\end{tabular}

${ }^{*} 1$ Light intensity, $3800 \mathrm{~lx}$

*2 The number of embryos was counted at the end of each culture.

*3 Figures in parethesis denote the percentage of healthy plantlets that developed from globular or heart embryos during the second regeneration stage. These figures were obtained by comparing the results in Fig. 2-B and Table 1. It is assumed that all torpedo embryos became healthy plantlets during the second regeneration stage. 
Table 2. Effect of light intensity on morphological development during the first regeneration stage at 18 days $^{* 1}$.

\begin{tabular}{cccccc}
\hline & \multicolumn{5}{c}{ Number of embryos developed $(/ \mathrm{L})^{* 2}$} \\
\hline$(\mathrm{lx})$ & 0 & 1,300 & 2,300 & 3,300 & 4,500 \\
\hline \multirow{2}{*}{ globular, heart } & 305,000 & 335,000 & 375,000 & 420,000 & 385,000 \\
torpedo & $(9.8 \%)^{* 3}$ & $(9.6 \%)$ & $(8.0 \%)$ & $(6.9 \%)$ & $(6.2 \%)$ \\
total & 8,000 & 8,000 & 10,000 & 16,000 & 33,000 \\
& 313,000 & 343,000 & 385,000 & 436,000 & 418,000 \\
\hline
\end{tabular}

${ }^{*} 1$ Photoperiod, $16 \mathrm{~h} / \mathrm{d}$

*2 The number of embryos was counted at 18 days.

*3 Figures in parethesis denote the percentage of healthy plantlets that developed from globular or heart embryos during second regeneration stage. These figures were obtained by comparing the results in Fig. 3-B and Table 2. It is assumed that all torpedo embryos became healthy plantlets during the second regenration

\section{Light-dependent morphological development during the second regeneration stage}

During the second regeneration stage, the developing plant cells gradually turned green and became larger, and then cotyledons appeared from the embryos formed during the first stage. These eventually became healthy plantlets. Fig. 4 shows the dependency on the photoperiod of healthy plantlet development during the second regeneration stage. Cells of less than $800 \mu \mathrm{m}$ in the 18-day culture under fixed light conditions (16-h photoperiod, $3800 \mathrm{~lx}$ ) were transferred to the second stage culture under various light conditions. The results indicate that the photoperiod considerably affected the number of plantlets obtained during the second stage, the highest level being with a 16 -h photoperiod at 14 days, which was approximately two times of the number of healthy plantlets obtained under dark conditions. Even under dark conditions, 9000 plantlets per liter of medium were obtained. However, all these plantlets were etiolated and small compared with those produced under the photoperiod of $16 \mathrm{~h}$. The chlorophyll content reached a plateau at a photoperiod of $12 \mathrm{~h}$.

The number of healthy plantlets increased with increasing light intensity in the 16-h photoperiod during the second stage, while the chlorophyll content showed the highest level in the cultures at

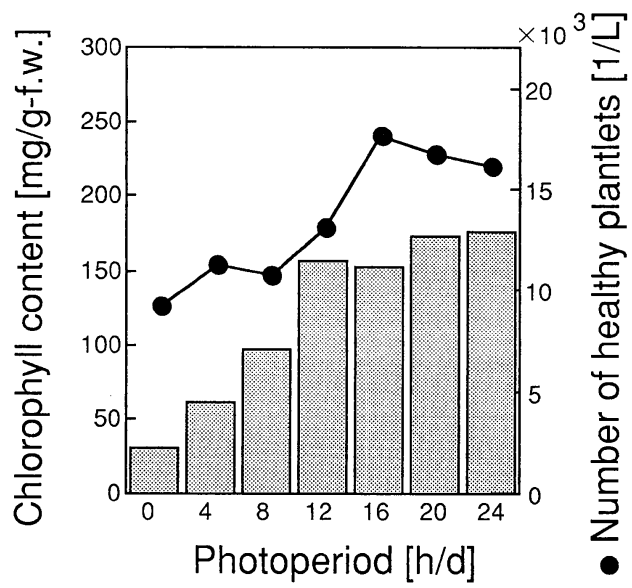

Fig. 4 Effect of photoperiods on plantlet development in the second regeneration stage.

Cells cultured for 18 days with a 16 -h photoperiod and at $3800 \mathrm{~lx}$ during the first regeneration stage

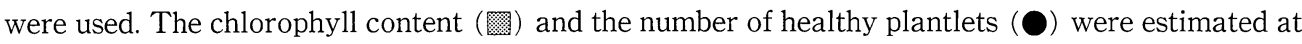
the end of the second regeneration stage. 


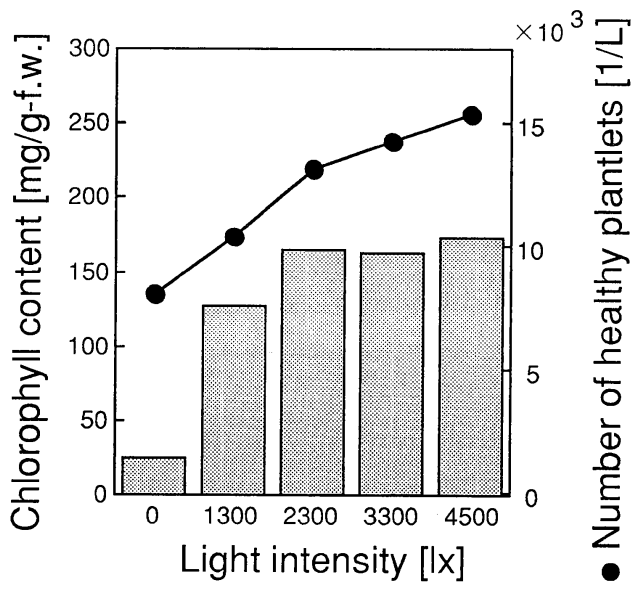

Fig. 5 Effect of light intensity on chlorophyll content and number of healthy plantlets in the second regeneration stage.

The chlorophyll content (피) and the number of healthy plantlets the second regeneration stage.

more than 2300 lx (Fig. 5). The average size of the plantlets appeared to become larger as the light intensity increased. Thus, photosynthesis seemed to contribute strongly to the development of plantlets during the sceond regeneration stage.

In conclusion, light dependency for celery was relatively low during the first regeneration stage, and a photoperiod of more than $16 \mathrm{~h}$ with a high intensity of light was required for healthy plantlet development in the second regeneration stage. Our results suggest that light will affect the regeneration frequency of other plants. The approach demonstrated here will contribute to artificial seed production using hairy roots ${ }^{17}$. We now intend to develop a bioreactor that can incorporate illumination and to carry out efficient culture on the basis of earlier biotechnological results ${ }^{18-23)}$.

\section{References}

1) Reinert, J., 1958. Naturwissenschaft, $45: 344-345$.

2) Steward, F., M. Mapes, K. Mears, 1958. Am. J. Bot., 45 : 705-708.

3) Murashige. T., 1987. In "Frontiers of plant tissue culture. International Association of Plant Tissue Culture". (ed. by Thorpe, T.), p. 15-16, Calgary, Canada.

4) Redenbaugh, K., B. D. Paasch, J. W. Nichol, M. E. Kossler, P. R. Viss, K. A. Walker, 1986. Bio/Technology, $4: 797-801$.

5) Redenbaugh, K., D. Slade, P. Viss, J. A. Fujii, 1987. Hort Science, $22: 803-809$.

6) Redenbaugh. K., 1990. Hort Science, $25: 251-255$.

7) Slade, D., J. A. Fujii, K. Redenbaugh, 1989. J. Tissue Culture Methods, 12 : 179-183.

8) Salisbury, F. B., C. W. Ross, 1978. Plant Physiology : 290-303. Wadswerth Publishing Company, Inc., Belmont, USA

9) Pierik, R. L. M., 1987. In Vitro Culture of Higher Plants : 145. Martinus Nijhoff Publishers, Dordrecht, The Netherlands

10) Ohnishi, N., T. Kawano, S. C. Smith, D. Stuart, 1988. Japan. J. Breed. 38 (bessatu 2) : 46-47.

11) Onishi, N., T. Mashiko, A. Okamoto, 1992. Abstracts of International symposium on transplant production systems, Yokohama Japan : C26.

12) Okamoto, A., H. Sakurazawa, T. Kobayashi, 1992. Plant Tissue Culture Lett., $9: 22-26$.

13) Schenk, R. U., A. C. Hildebrandt, 1972. Can. J. Bot., 50 : 199-204. 
14) Arnon, D. I., 1949. Plant Physiol., 24 : 1-15.

15) Kitto, S. L., Janick, 1985. J. Amer. Soc. Hort. Sci., $110: 277-282$.

16) Kamada, H., K. Kobayashi, T. Kiyosue, H. Harada,1989. In Vitro Cell Dev. Biol., 25 : 1163-1166.

17) Uozumi, N., Y. Nakashimada, Y. Kato, T. Kobayashi, 1992. J. Ferment. Bioeng., 74 : 21-26.

18) Taya, M., A. Yoyama, O. Kondo, T. Kobayashi, 1989. J. Chem. Eng. Japan, 22:84-89.

19) Taya, M., A. Yoyama, R. Nomura, O. Kondo, C. Matsui, T. Kobayashi, 1989b. J. Ferment. Bioeng., 67 : $31-34$.

20) Kondo, O., H. Honda, M. Taya, T. Kobayashi, 1990. Appl. Microbiol. Biotechnol., 33 : 291-294.

21) Kato, Y., N. Uozumi, T. Kimura, H. Honda, T. Kobayashi, 1991. Plant Tissue Culture Lett., 8 : 158-165.

22) Uozumi, N., K. Kohketsu, O. Kondo, H. Honda, T. Kobayashi, 1991. J. Ferment. Bioeng., 72 : 457-460.

23) Uozumi, N., Y. Kato, Y. Nakashimada, T. Kobayashi, 1992. Appl. Microbiol. Biotechnol., 37 : 560-565.

\title{
《和文要約》
}

懸濁培養におけるセロリ不定胚および小植物体形成に与える光照射の影響

\author{
魚住信之・䋶䋶克人・岡本彰宏*・小林猛 \\ 名古屋大学工学部生物機能工学科 \\ *キリンビール(株) 植物開発研究所
}

人工種子の封入体に用いるセロリ小植物形成までの懸濁培養を 2 段階に分けて光照射依存性を検討した. カルスから魚雷型不定胚を形成する第 1 段階では暗所でも魚雷型胚が形成され，光照射の節約が可能である と考えられた。第 2 段階の小植物体誘導期では健全な小植物体形成には光照射は必須であり，照射時間は 16 時間/日が最適で光強度は $4,500 \mathrm{~lx}$ までは強度に依存して促進された。 